\title{
Analysis of the Impact of Special Tax Regimes for Small Business Financial Results
}

\author{
Tufetulov A.M.a \\ Davletshin T.G. ${ }^{b}$ \\ Salmina S.V. ${ }^{c}$ \\ ac Kazan Federal University, Institute of Management, Economics and Finance, Kazan, 420008, Russia \\ ${ }^{b}$ Chief Executive Officer of «Volga Melnik», Kazan, 420008, Russia \\ Email: ajdar-t@yandex.ru
}

\section{Doi:10.5901/mjss.2015.v6n1s3p503}

\section{Abstract}

This article is about taxation of the small business enterprises on simplified system of the taxation are considered. The comparative analysis of the financial results of the company on the general system and simplified system of the taxation under otherwise identical conditions are investigated. Proposed changes to obviate the disadvantages of the tax legislation. As an improvement it is possible to avoid the above-named problems in the simple way: to exclude item 5 from Art. 173 of the Tax Code of the Russian Federation with simultaneous reduction of the top threshold of work on the simplified tax system mode for example by 10 times, i.e. to 6 million rubles. This step would be real support of small business in the production sphere and would lead to that small enterprises in the production sphere would receive serious incentive to development, and the state would raise a collecting of taxes and would receive one more tool in fight against firms engaged encashment.

Keywords: special tax regime, general tax regime, simplified system of the taxation, VAT, profit, profitability, small business.

\section{Introduction}

It is known that the general tax regime (the general system of the taxation) is a system of the taxation at which the economic entity pays the taxes and fees established by the Tax code of the Russian Federation if it is not exempted from their payment.

The special tax modes represent the special, established to the Tax Code of the Russian Federation order of definition of elements of taxes, and also release from tax payment and collecting under certain conditions. These tax modes are directed on creation of more favorable economic and financial conditions of activity of the organizations, the individual entrepreneurs belonging to the sphere of small business, agricultural producers and participants of implementation of production sharing agreements.

Treat the special tax modes:

- $\quad$ system of the taxation for agricultural producers;

- $\quad$ simplified system of the taxation;

- system of the taxation in the form of the single tax on imputed income for separate kinds of activity;

- system of the taxation at implementation of production sharing agreements;

- patent system of the taxation.

Some authors, such as Abbas S.M.A. [1], Sidlyar V.V. [2], Gale W. [3] discuss special tax regimes. At first sight, the special tax treatments carry out completely the function and give real opportunity to the organizations to optimize the tax load, thereby stimulating development of small business. However, due to the lack of harmonization of the relations between the enterprises on general system of the taxation and special modes, this mission of special tax modes for small business often is not realized, and for the organizations of the production sphere and construction, where the subject of small business realizes the goods (works, services) to larger enterprises working at general system of the taxation, on the contrary, leads to considerable deterioration of financial results.

The taxation of small businesses discussed in the article by authors such as Adebisi J.F., Eragbhe E., Cavalcanti R.D.O. [4], [5], [6], Cho M. [7], Hurst E. [8], Hebert R.F. [9], Henrekson M. [10], Gartner W.B. [11], Hansford A. [12]. 


\section{Theory}

The analysis shows that if the enterprise on the simplified tax system realizes the production to the population or the enterprises on the simplified tax system, on the one hand, it simplifies conducting accounting, and with another, reduces the tax load. If the enterprise is on a special tax mode and realizes the production to the enterprises on general system of the taxation, there are problems with pricing: goods (works, services) the enterprises on a special mode are demanded for the enterprises on general system of the taxation at the price, reduced by a rate of the VAT of 18 (10) \%.

The reason of it is covered in imperfection of chapter 21 of the Tax Code of the Russian Federation «Value added tax». At an operating method of calculation of the VAT for payment is defined as a difference between a tax from realization of goods (works, services) and a «entrance» tax. Thus, if the enterprise working at the general system of the taxation, buys goods (works, services) from the enterprise which is not paying the VAT, he has nothing to put on a deduction, and the enterprise on general system of the taxation sustains financial losses of $18(10) \%$ of the buying price. Therefore, the enterprises on the simplified tax system are «undesirable» suppliers for the enterprises on general system of the taxation. At this Tax Code of the Russian Federation allows exposure to the buyer of invoices with the allocated VAT the enterprises on the simplified tax system, however, the standard of item 5 of Art. 173 of the Tax Code of the Russian Federation, orders to small enterprise to pay the sum of the VAT specified in the invoice, of the budget on a special mode. De facto the Tax Code of the Russian Federation imposes the receipts tax on a rate of the VAT of 18 (10) $\%$ for operations between the enterprises on general system of the taxation and a special mode. Thus, the taxpayer applying a special tax mode, sustains financial losses twice: it cannot put to a VAT deduction from acquired production and is besides compelled to reduce the price of goods (works, services) for a VAT rate that it was favorable to the buyer who is the payer of the VAT to work with it.

It should be noted that absence understanding of essence of a value added tax at conceptual level is the reason of defects of chapter 21 of the Tax Code of the Russian Federation. In particular, even among experts, the wrong opinion is widespread that financial results of the enterprises applying special modes, despite reduction of the price by a VAT rate, are absolutely equal with those who is on general system of the taxation.

\section{Results}

To disprove this opinion, we carried out the small analysis of influence of the taxation on financial results of two conditional organizations applying general system of the taxation and the simplified tax system, other things being equal managing, the realizable goods (works, services) to the enterprise on the simplified tax system and to the enterprise on general system of the taxation. For this purpose we considered two options of relationship between the enterprises:

- $\quad$ the buyer - the enterprise being on the simplified tax system or the natural person.

- the buyer - the enterprise being on general system of the taxation.

In the first case, for the buyer does not matter, what tax treatment at the seller and therefore the goods price (works, services) will be identical to both sellers.

At the enterprise on the simplified tax system the «entrance» VAT is not compensated, and belongs on prime cost, other things being equal profit to the taxation of the enterprise is one sum one simplified tax system less than the «entrance» VAT on goods (to works, services) that it is possible to reflect a formula (1):

Profit (simplified tax system) $=$

Profit (general system of the taxation) + VAT (exiting) - VAT (entrance) (1)

In this case at calculations are not taken into account the property tax sum which in small business while is insignificant, and also privileges on contributions to social funds which improve indicators of profitability of the enterprise on the simplified tax system a little that can give a small mathematical error.

The structure of expenses, the price of production and financial results are given in the fig. 1 (to the taxation) the enterprises depending on the tax treatment (or general system of the taxation), other things being equal, from which it is visible to the simplified tax system that profit at the enterprise is one simplified tax system considerable. 


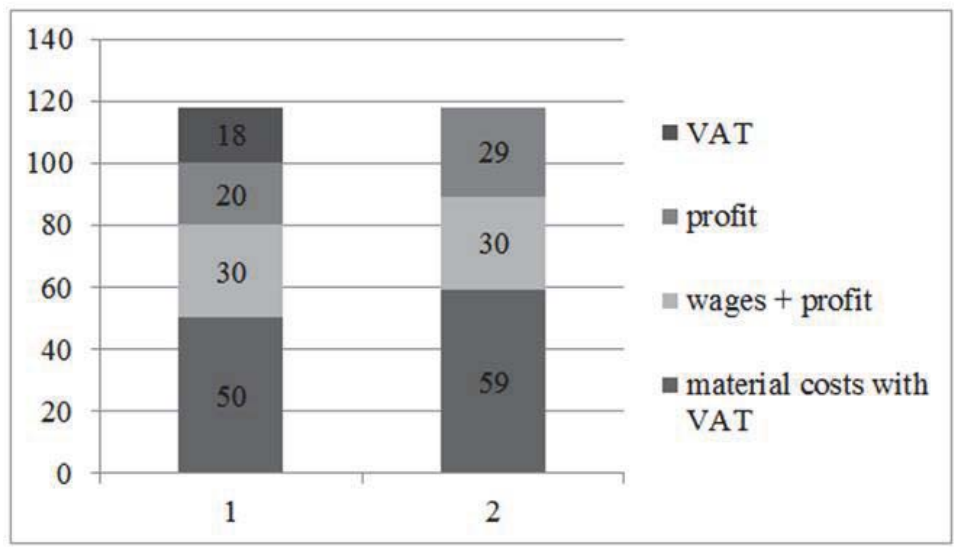

Fig.1. The structure of expenses, the price of production and financial results.

1. The price of production, costs of production and enterprise profit of general system of the taxation from the VAT of $18 \%$.

2. The price of production, costs of production and enterprise profit of the simplified tax system.

The net profit of the enterprise on general system of the taxation after tax discharge on profit will make: $20-$ $20 * 20 \%=16 \%$, and the enterprises on the simplified tax system: $29-29 * 15 \%=24,65 \%$.

Further we will consider a case, realization of goods (works, services) to the buyer on general system of the taxation when the price of the seller of the simplified tax system is rate VAT lower, than the price at the seller of general system of the taxation to be competitive in comparison with the prices of the seller of general system of the taxation. At the enterprise on the simplified tax system the «entrance» VAT is not compensated, and belongs on prime cost, with other things being equal the profit to the taxation of the enterprise is one sum one simplified tax system less than the «entrance» VAT on goods (works, services) that it is possible to reflect a formula (2):

Profit (simplified tax system) $=$

Profit (general system of the taxation) - VAT (entrance) (2)

Figure 2 shows the structure of the costs, the price of products and financial results (pre-tax) of enterprises, depending on the tax regime, ceteris paribus, which shows that the profits from the enterprise to the simplified system of the taxation in this case is much lower than organization on the basis.

The structure of expenses, the price of production and financial results (to the taxation) the enterprises depending on the tax treatment (general system of the taxation are given in the fig. 2 or to the simplified tax system), with other things being equal, from which it is visible that the profit at the enterprise on the simplified tax system in this case is much lower, than the organizations on general system of the taxation.

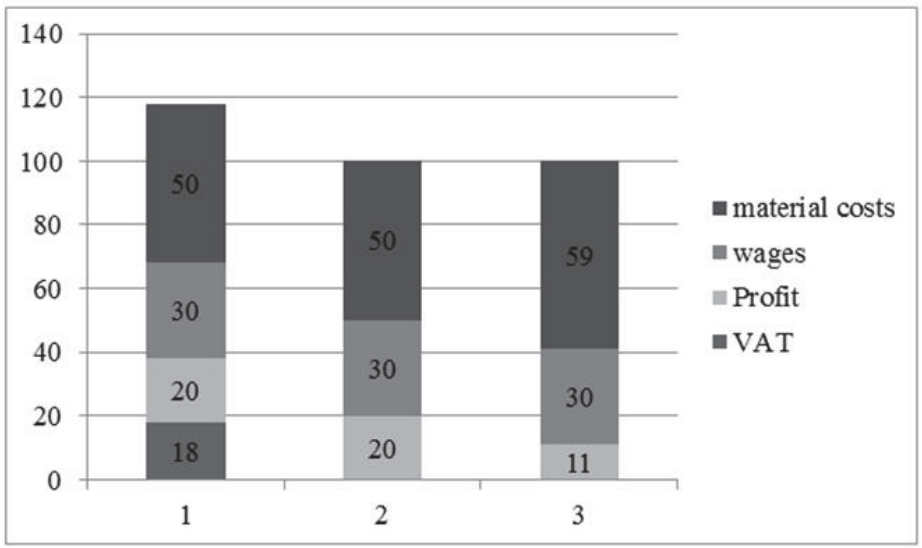

Fig.2. The structure of expenses, the price of production and financial results. 
1. The price of production, costs of production and enterprise profit of general system of the taxation from the VAT of $18 \%$.

2. The price of production, costs of production and enterprise profit of general system of the taxation without the VAT.

3. The price of production, costs of production and enterprise profit of the simplified tax system.

The net profit of the enterprise on general system after tax discharge on profit will make $20-20 \star 20 \%=16$, and the enterprises on the simplified tax system of $11-11 * 15 \%=9,35 \%$. Thus, in a standard situation for small business, the net profit on the simplified tax system is approximately twice less, than on general system of the taxation.

\section{Conclusions}

The above-stated analysis shows that application of special tax modes profitable in the sphere of home shopping service and services to the population, and is unprofitable in the production sphere and construction where buyers of goods (works, services) small enterprise are larger enterprises applying general system of the taxation. As a result, the organizations of small business working in a legal framework, reducing the price of the production of a VAT rate, or, selling the production at the price of the enterprise of general system, but paying to the budget $18 \%$ of a tax according to item 5 of Art. 173 of the Tax Code of the Russian Federation, unfairly sustain considerable financial losses and are noncompetitive in the Russian market that also provokes the enterprises to address to short-lived firms for the purpose of evasion from so considerable tax by «illegal» compensation of the VAT.

As an improvement it is possible to avoid the above-named problems in the simple way: to exclude item 5 from Art. 173 of the Tax Code of the Russian Federation with simultaneous reduction of the top threshold of work on the simplified tax system mode for example by 10 times, i.e. to 6 million rubles. This step would be real support of small business in the production sphere and would lead to that small enterprises in the production sphere would receive serious incentive to development, and the state would raise a collecting of taxes and would receive one more tool in fight against firms engaged encashment.

\section{References}

Abbas S.M.A., Klemm A. A partial race to the bottom: Corporate tax developments in emerging and developing economies // International Tax and Public Finance Volume 20, Issue 4. - 2013. - pp. 596-617.

Sidlyar V.V. Theoretical and organizational basis for determination of special tax regimes // Actual Problems of Economics, Issue 12. 2008. - pp. 161-167.

Gale W., Brown S. Small business, innovation, and tax policy: A review // National Tax Journal Volume 66, Issue 4. - 2013. - pp. 871892.

Adebisi J.F., Gbegi D.O. Effect of multiple taxation on the performance of small and medium scale business enterprises. (A study of West African Ceremics Ajeokuta, Kogi State) // Mediterranean Journal of Social Sciences Volume 4, Issue 6. - 2013. - pp. 323334.

Eragbhe E., Omoye A.S. SME characteristics and value added tax compliance costs in Nigeria // Mediterranean Journal of Social Sciences Volume 5, Issue 20. - 2014. - pp. 614-620.

Cavalcanti R.D.O., Erosa A. A theory of capital gains taxation and business turnover // Economic Theory Volume 32, Issue 3. - 2007. pp. 477-496.

Cho M. The effect of capital gains taxation on small business transfers and start-ups // Economic Modelling Volume 36. - 2014. - pp. 447-454.

Hurst E., Pugsley B.W. What do small business do? // Brookings Papers on Economic Activity, Issue 2. - 2011. - pp. 73-118.

Hebert R.F., Link A.N. The entrepreneur as innovator // Journal of Technology Transfer Volume 31, Issue 5. - 2006. - pp. 589-597.

Henrekson M., Sanandaji T. Small business activity does not measure entrepreneurship // Proceedings of the National Academy of Sciences of the United States of America Volume 111, Issue 5. - 2014. - pp.1760-1765.

Gartner W.B. What are we talking about when we talk about entrepreneurship? // Journal of Business Venturing Volume 5, Issue 1. 1990. - pp. 15-28.

Hansford A., Hasseldine J. Tax compliance costs for small and medium sized enterprises: The case of the UK // eJournal of Tax Research Volume 10, Issue 2. - 2012. - pp. 288-303.

Adigamova Farida F., Safiullin Marat A., Tufetulov Aidar M. Mechanism of state tax regulation in the global economy // Mediterranean Journal of Social Sciences vol. 5 № 24, November 2014, pp. 193-199. 